\title{
Regulation of CYP27B1 mRNA Expression in Primary Human Osteoblasts
}

\author{
K. van der Meijden ${ }^{1}$ - H. W. van Essen $^{2}$ - F. W. Bloemers ${ }^{3}$ E. A. J. M. Schulten ${ }^{4}$. \\ P. Lips ${ }^{1} \cdot$ N. Bravenboer ${ }^{2}$
}

Received: 1 December 2015/Accepted: 11 March 2016/Published online: 25 March 2016

(C) The Author(s) 2016. This article is published with open access at Springerlink.com

\begin{abstract}
The enzyme 1 $\alpha$-hydroxylase (gene CYP27B1) catalyzes the synthesis of $1,25(\mathrm{OH})_{2} \mathrm{D}$ in both renal and bone cells. While renal $1 \alpha$-hydroxylase is tightly regulated by hormones and $1,25(\mathrm{OH})_{2} \mathrm{D}$ itself, the regulation of $1 \alpha-$ hydroxylase in bone cells is poorly understood. The aim of this study was to investigate in a primary human osteoblast culture whether parathyroid hormone (PTH), fibroblast growth factor 23 (FGF23), calcitonin, calcium, phosphate, or MEPE affect mRNA levels of CYP27B1. Our results show that primary human osteoblasts in the presence of high calcium concentrations increase their CYP27B1 mRNA levels by 1.3 -fold. CYP27B1 mRNA levels were not affected by PTH1-34, rhFGF23, calcitonin, phosphate, and rhMEPE. Our results suggest that the regulation of bone $1 \alpha$-hydroxylase is different from renal $1 \alpha$-hydroxylase. High calcium concentrations in bone may result in an increased local synthesis of $1,25(\mathrm{OH})_{2} \mathrm{D}$ leading to an
\end{abstract}

Electronic supplementary material The online version of this article (doi:10.1007/s00223-016-0131-9) contains supplementary material, which is available to authorized users.

N. Bravenboer

n.bravenboer@vumc.nl

1 Department of Internal Medicine/Endocrinology, VU University Medical Center, Research Institute MOVE, Amsterdam, The Netherlands

2 Department of Clinical Chemistry, VU University Medical Center, Research Institute MOVE, PO Box 7057, 1007 MB Amsterdam, The Netherlands

3 Department of Trauma Surgery, VU University Medical Center, Amsterdam, The Netherlands

4 Department of Oral and Maxillofacial Surgery/Oral Pathology, VU University Medical Center, Academic Centre for Dentistry Amsterdam (ACTA), Amsterdam, The Netherlands enhanced matrix mineralization. In this way, the local synthesis of $1,25(\mathrm{OH})_{2} \mathrm{D}$ may contribute to the stimulatory effect of calcium on matrix mineralization.

Keywords CYP27B1 - Primary human osteoblasts · Calcium - Parathyroid hormone - Fibroblast growth factor 23 - Matrix extracellular phosphoglycoprotein

\section{Introduction}

The calciotropic hormone 1,25-dihydroxyvitamin D $\left(1,25(\mathrm{OH})_{2} \mathrm{D}\right)$ is synthesized by the mitochondrial enzyme 25 -hydroxyvitamin $\mathrm{D}$-1 $\alpha$-hydroxylase (1 $\alpha$-hydroxylase) encoded by the gene CYP27B1 [33]. The enzyme 1 $\alpha$-hydroxylase is predominantly expressed in the proximal tubular cells of the kidney which is the major source of circulating $1,25(\mathrm{OH})_{2} \mathrm{D}$ [11]. Extra-renal sites of $1 \alpha$-hydroxylase expression such as bone cells are responsible for the local synthesis of $1,25(\mathrm{OH})_{2} \mathrm{D}$ [2]. Both renal and bone cells express identical $1 \alpha$-hydroxylase proteins, however, the regulation of $1 \alpha$-hydroxylase at these sites is different $[3,4,26]$. While renal $1 \alpha$-hydroxylase is tightly regulated by hormones and $1,25(\mathrm{OH})_{2} \mathrm{D}$ itself [61], the regulation of $1 \alpha$-hydroxylase in bone cells is poorly understood.

Renal $1 \alpha$-hydroxylase expression and activity are strictly regulated by the hormones parathyroid hormone (PTH) and fibroblast growth factor 23 (FGF23) [61]. PTH is secreted by the parathyroid glands in response to low serum calcium concentrations and induces renal CYP27B1 expression [19]. FGF23 is secreted by osteocytes and osteoblasts in response to phosphate loading or high serum $1,25(\mathrm{OH})_{2} \mathrm{D}$ concentrations [41]. FGF23 mainly acts on the kidney by inhibiting renal tubular phosphate reabsorption, but it also suppresses renal CYP27B1 expression [41, 47]. 
Direct effects of calcium on CYP27B1 expression have also been reported $[9,19]$. A low calcium concentration increases CYP27B1 expression and a high calcium concentration reduces CYP27B1 expression in transformed human proximal tubule cells and primary mouse kidney cells [9, 19] Whether phosphate directly regulates CYP27B1 expression in renal cells remains controversial. In primary mouse kidney cells, low phosphate conditions increase the activity of $1 \alpha$-hydroxylase [14, 19], but direct effects of phosphate have not been confirmed by other investigators [24, 25, 45]. Another hormone involved in the regulation of $1 \alpha$-hydroxylase may be calcitonin, which is synthesized by C-cells of the thyroid gland [43]. Although in humans the role of calcitonin in the regulation of $1 \alpha$ hydroxylase has been questioned [27], several animal studies show stimulatory effects of calcitonin on renal CYP27B1 expression [28, 31, 43, 52].

Previously, we revealed that in primary human osteoblasts $1,25(\mathrm{OH})_{2} \mathrm{D}$ did not affect CYP27B1 expression [58], suggesting that bone $1 \alpha$-hydroxylase is not regulated as renal $1 \alpha$-hydroxylase. However, whether the other renal regulators can affect bone $1 \alpha$-hydroxylase has not been fully elucidated. PTH exerts its effects through binding to the PTH receptor 1 (PTH1R) which is present in osteoblasts [53], but effects of PTH on CYP27B1 expression seem to be controversial. In the human osteoblast cell line SV-HFO and rat osteosarcoma cell line ROS 17/2.8, PTH does not regulate expression and activity of CYP27B1 [55, 59]. However, in primary cells including human bone cells and mesenchymal stem cells a stimulatory effect of PTH has been shown on $1 \alpha$ hydroxylase expression and activity [21, 53]. FGF23 can inhibit extra-renal expression of CYP27B1 as shown in monocyte cultures [7], but whether FGF23 modulates CYP27B1 expression in bone cells is unknown. Due to undetectable Klotho mRNA levels in bone cells, FGF23 can bind fibroblast growth factor receptor (FGFR) only with low affinity [56]. Nevertheless, there is evidence that supraphysiological concentrations of FGF23 are able to affect bone cells [63]. Calcium does not appear to modulate $1 \alpha-$ hydroxylase expression and activity in SV-HFO osteoblasts [59]. Phosphate increases CYP27B1 mRNA expression in the mouse IDG-SW3 cell line [29]. Whether calcium or phosphate affects CYP27B1 expression in primary human bone cells is unknown. Regarding calcitonin, primary human osteoblasts express the calcitonin receptor (CTR) [62], but effects of calcitonin on the expression of CYP27B1 in bone cells have not yet been investigated.

Due to the local function of $1,25(\mathrm{OH})_{2} \mathrm{D}$ synthesis in bone, for instance stimulation of osteoblast differentiation and mineralization in an autocrine or paracrine way $[5,58$, 59], we hypothesized that the enzyme $1 \alpha$-hydroxylase is regulated at a local level. A factor that may be involved in this regulation of local $1,25(\mathrm{OH})_{2} \mathrm{D}$ concentrations in bone is matrix extracellular phosphoglycoprotein (MEPE). MEPE is a member of the Small Integrin Binding Ligand N-linked Glycoprotein (SIBLING) family and is predominantly expressed in osteocytes and osteoblasts [44, 46]. Animal studies show that MEPE inhibits renal phosphate reabsorption and reduces intestinal phosphate absorption [15, 39]. Similar to FGF23, MEPE also inhibits bone mineralization [23, 63]. In ex vivo cultures of MEPE knockout mouse osteoblasts, an increased amount of mineralized nodules was observed compared to wild-type osteoblast cultures [23]. Bone mineralization is also modulated by locally synthesized $1,25(\mathrm{OH})_{2} \mathrm{D}$ as shown in vitro $[5,59]$. Synthesis of $1,25(\mathrm{OH})_{2} \mathrm{D}$ from $25(\mathrm{OH}) \mathrm{D}$ by osteoblasts in culture leads to an increased matrix mineralization [5, 59]. Because $1,25(\mathrm{OH})_{2} \mathrm{D}$ and MEPE are both involved in bone mineralization [5, 23, 59], MEPE may be able to regulate CYP27B1 expression in bone. Due to the stimulatory effect of $1,25(\mathrm{OH})_{2} \mathrm{D}$ on matrix mineralization $[5,59]$, we hypothesized that MEPE acts as an inhibitor of bone CYP27B1.

The aim of the present study was to investigate in a primary human osteoblast culture whether PTH, FGF23, calcitonin, calcium, phosphate, or MEPE affect mRNA levels of CYP27B1. Since the function of extra-renal synthesis of $1,25(\mathrm{OH})_{2} \mathrm{D}$ is different from that of the renal synthesis of $1,25(\mathrm{OH})_{2} \mathrm{D}[5,59]$, we hypothesized that the renal regulators do not affect CYP27B1 mRNA levels in primary human osteoblasts. Regarding MEPE, we hypothesized that it reduces mRNA levels of CYP27B1. Because the impact of locally synthesized $1,25(\mathrm{OH})_{2} \mathrm{D}$ on bone cells not only depends on the concentration, but also on expression levels of the vitamin D receptor (VDR), we determined VDR mRNA levels in primary human osteoblasts as well.

\section{Materials and Methods}

\section{Primary Human Osteoblast Culture}

Primary human osteoblasts were isolated from redundant trabecular bone fragments obtained from healthy donors undergoing pre-implant bony reconstruction of the mandible or maxilla with autologous bone from the anterior iliac crest. Trabecular bone fragments were also obtained from femoral heads from patients who underwent orthopedic surgery for fractures of the femoral neck. The donor group consisted of 10 males and 7 females with a mean age of $56.2 \pm 4.6$ years. The protocol was approved by the Medical Ethical Review Board of the VU University Medical Center, Amsterdam, The Netherlands, and all donors gave their written informed consent.

A modification of the methods of Beresford et al. and Marie et al. $[8,37]$ was used to obtain a primary human 
osteoblast culture, as described previously [58]. Shortly, the trabecular bone fragments were minced into small pieces and washed extensively with phosphate-buffered saline (PBS). The bone pieces were treated with $2 \mathrm{mg} / \mathrm{ml}$ collagenase type II $(300 \mathrm{U} / \mathrm{mg}$; Worthington Biochemical Corporation, Lakewood, NJ, USA) for $2 \mathrm{~h}$ in a shaking waterbath at $37^{\circ} \mathrm{C}$. The pieces were placed in culture flasks with Dulbecco's Modified Eagle Medium: Nutrient Mixture F-12 (DMEM/F12; Gibco, Life technologies, Grand Island, NY, USA) supplemented with $10 \%$ Fetal Clone I (HyClone; Thermo Fisher Scientific, Rockford, IL, USA), $100 \mathrm{U} / \mathrm{ml}$ penicillin and $100 \mu \mathrm{g} / \mathrm{ml}$ streptomycin (Gibco; Life technologies), $1.25 \mu \mathrm{g} / \mathrm{ml}$ fungizone (Gibco; Life technologies) and incubated at $37{ }^{\circ} \mathrm{C}$ in a humidified air with $5 \% \mathrm{CO}_{2}$. Medium was changed twice a week until cells reached confluence.

\section{Primary Human Osteoblast Treatments}

Primary human osteoblasts of the first or second passage were seeded into a 12 -wells plate at a cell density of 40.000 cells/well. Cells were allowed to attach to the well for $24 \mathrm{~h}$. Subsequently, primary human osteoblasts were incubated in medium supplemented with human PTH fragment 1-34 (PTH1-34; Sigma-Aldrich, St. Louis, MO, USA), recombinant human FGF23 protein (rhFGF23; R\&D Systems, Minneapolis, MN, USA), human calcitonin (SigmaAldrich), calcium chloride ( $\mathrm{CaCl}_{2}$; Sigma-Aldrich), sodium dihydrogen phosphate $\left(\mathrm{NaH}_{2} \mathrm{PO}_{4} ;\right.$ Merck, Darmstadt, Germany), or recombinant human MEPE (rhMEPE; R\&D systems). Cells were treated with four different concentrations ranging from physiological to supra-physiological of PTH (50-50,000 pg/ml), FGF23 (25-25,000 pg/ml), and calcitonin $(2-2000 \mathrm{pg} / \mathrm{ml})$. Three different concentrations of rhMEPE (0.05-5 $\mu \mathrm{g} / \mathrm{ml}$; physiological concentrations of MEPE: $0.02-1.3 \mu \mathrm{g} / \mathrm{ml}$ ) were used, as published previously [32]. Supplementation of four different concentrations of calcium $(0.5-3.0 \mathrm{mmol} / \mathrm{l})$ was performed in DMEM without calcium (Gibco; Life technologies). Supplementation of four different concentrations of phosphate $(0.5-3.0 \mathrm{mmol} / \mathrm{l})$ was performed in DMEM without phosphate (Gibco; Life technologies). Incubation of primary human osteoblasts in PTH1-34, rhFGF23, calcitonin, or rhMEPE was performed in DMEM/F12 containing $1.1 \mathrm{mmol} / \mathrm{l} \mathrm{calcium}$ and $1.0 \mathrm{mmol} / \mathrm{l}$ phosphate. All experiments were performed in medium with $5 \%$ Fetal Clone I. After $24 \mathrm{~h}$ of incubation, cells were lysed for total RNA isolation as described below.

\section{RNA Isolation and RT-qPCR}

Total RNA isolation of primary human osteoblasts was performed using the RNeasy Mini Kit (Qiagen, Hilden,
Germany) according to the manufacturer's protocol. For removing residual DNA amounts, an additional on-column DNAse treatment was accomplished during the RNA isolation procedure. Total RNA concentrations were measured by the Nanodrop spectrophotometer (Nanodrop Technologies, Wilmington, DE, USA).

RNA was reverse transcribed from 100 ng total RNA in a $20-\mu$ reaction mixture containing $5 \mathrm{mmol} / 1 \mathrm{MgCl}_{2}$ (Eurogentec, Maastricht, The Netherlands), 1x RT buffer (Promega, Madison, WI, USA), $1 \mathrm{mmol} / \mathrm{l} \mathrm{dATP}, 1 \mathrm{mmol} / \mathrm{l}$ dCTP, $1 \mathrm{mmol} / \mathrm{l} \mathrm{dGTP}, 1 \mathrm{mmol} / \mathrm{l}$ dTTP (Roche Diagnostics, Mannheim, Germany), $1 \mathrm{mmol} / \mathrm{l}$ betaïne, $10 \mathrm{ng} / \mathrm{ul}$ random primer, $0.4 \mathrm{U} / \mu \mathrm{l}$ RNAsin (Promega), and $5 \mathrm{U} /$ $\mu 1$ M-MLV RT-enzyme (Promega), as described previously [58]. The PCR reaction of total $25 \mu \mathrm{l}$ contained $3 \mu \mathrm{l}$ cDNA, $300 \mathrm{nmol} / 1$ reverse and forward primer, and SYBR Green Supermix (Bio-Rad Laboratories Inc., Veenendaal, The Netherlands). The following primer sets were used: CYP27B1 forward: 5'-TGGCCCAGATCCTAACACAT TT-3', reverse: 5'-GTCCGGGTCTTGGGTCTAACT-3'; VDR forward: 5'-GGACGCCCACCATAAGACCTA-3', reverse: 5'-CTCCСТCСАCCATCATTCACA-3'; osterix forward: 5'-TACCCCATCTCCCTTGACTG-3', reverse: 5'-TCTCCATAACCATGGCAACA-3'; runt-related transcription factor 2 (RUNX2) forward: $5^{\prime}$-CGCATTCCTCA TCCCAGTAT-3', reverse: 5'-GCC-TGG-GGT-CTG-TA A-TCT-GA-3'; collagen type $1 \alpha 1(\mathrm{COL} 1 \alpha 1)$ forward: $5^{\prime}$ GTGCTAAAGGTGCCAATGGT- ${ }^{\prime}$, reverse: $5^{\prime}$-ACCAG GTTCACCGCTGTTAC- ${ }^{\prime}$, alkaline phosphatase (ALP) forward: $5^{\prime}$-CCACGTCTTCACATTTGGTG-3', reverse: 5'-GCAGTGAAGGGCTTCTTGTC-3'; osteopontin forward: $5^{\prime}$-TTCCAAGTAAGTCCAACGAAAG- $3^{\prime}$, reverse: 5'- GTGACCAGTTCATCAGATTCAT- $3^{\prime}$; osteocalcin forward: 5'-GCGCTACCTGTATCAATGGTATA-3', reverse: 5'-TCAGCCAACTCGTCACAGTC-3'; fibroblast growth factor 23 (FGF23) forward: 5'-TGAGCGTCCT CAGAGCCTAT-3' ${ }^{\prime}$, reverse: $5^{\prime}$-TTGTGGATCTGCAGGT GGTA-3'; dentin matrix protein 1 (DMP1) forward: 5'GATCAGCATCCTGCTCATGTT- $3^{\prime}$, reverse: $5^{\prime}$-AGCCA AATGACCCTTCCATTC- $3^{\prime}$ [6]; SOST forward: $5^{\prime}$ - ACC ACCCCTTTGAGACCAAAG- $3^{\prime}$, reverse: $5^{\prime}$-GGTCACGT AGCGGGTGAAGT- $3^{\prime}$ [6]; calcium-sensing receptor (CaSR) forward: $5^{\prime}$-TCAACCTGCAGTTCCTGCTGG-3', reverse: $5^{\prime}$-TGGCATAGGCTGGAATGAAGG- $3^{\prime}$ [30]; TATA-binding protein (TBP) forward: $5^{\prime}$-GGTCTG GGAAAATGGTGTGC-3', reverse: $5^{\prime}$-GCTGGAAAACC CAACTTCTG-3'. The PCR was performed on an iCycler $\mathrm{iQ}^{\mathrm{TM}}$ Real-Time PCR Detection System (Bio-Rad): $3 \mathrm{~min}$ at $95{ }^{\circ} \mathrm{C}, 40$ cycles consisting of $15 \mathrm{~s}$ at $95{ }^{\circ} \mathrm{C}$ and $1 \mathrm{~min}$ at $60{ }^{\circ} \mathrm{C}$. The relative gene expression was calculated by the $2^{-\Delta \mathrm{Ct}}$ method and TBP as well as succinate dehydrogenase subunit A (SDHA; Primerdesign, Rownhams, Southampton, United Kingdom) were used as reference genes. 


\section{Statistical Analysis}

Data are presented as mean \pm standard error of the mean (SEM). Of each factor a dose-response was tested using Friedman test followed by Dunn's post hoc test. A $p$ value $<0.05$ was considered to be statistically significant. Data were analyzed using GraphPad Prism 4 (Graphpad Software, San Diego, CA, USA).

\section{Results}

\section{Effects of PTH1-34, rhFGF23, or Calcitonin on mRNA Levels of CYP27B1 and VDR in Primary Human Osteoblasts}

Increasing concentrations of PTH1-34 (50-50,000 pg/ml) did not affect mRNA levels of CYP27B1 or VDR (Fig. 1a, $\mathrm{b}$, respectively). Increasing concentrations of rhFGF23 (25$25,000 \mathrm{pg} / \mathrm{ml}$ ) did also not affect mRNA levels of CYP27B1 and VDR (Fig. 1c, d, respectively), nor did calcitonin (2-2000 pg/ml; Fig. 1e, f, respectively).

\section{Effects of Calcium or Phosphate on mRNA Levels of CYP27B1 and VDR in Primary Human Osteoblasts}

Calcium and phosphate concentrations of $1.2 \mathrm{mmol} / \mathrm{l}$ were used as control because these concentrations closely resemble the concentrations of calcium and phosphate in DMEM/F12 supplemented with fetal bovine serum. High calcium concentrations increased CYP27B1 mRNA levels by 1.3 -fold $(p<0.01$; Fig. 2a), but an effect of low or high calcium concentrations on VDR mRNA levels was not observed (Fig. 2b). CYP27B1 and VDR mRNA levels were not affected by different concentrations of phosphate in medium (Fig. 2c, d, respectively).

\section{Effects of Calcium on mRNA Levels of Differentiation Markers in Primary Human Osteoblasts}

Because it has been shown that high calcium concentrations stimulate osteoblast differentiation and that more differentiated osteoblasts have a higher CYP27B1 activity $[3,35]$, we analyzed mRNA levels of several differentiation markers after incubation of osteoblasts in medium supplemented with increasing concentrations of calcium (Figs. 3a-i). High calcium concentrations increased mRNA levels of dentin matrix protein 1 (DMP1) by 35.5-fold $(p<0.05)$. Osterix, runt-related transcription factor 2 (RUNX2), collagen type $1 \alpha 1$ (COL $1 \alpha 1)$, alkaline phosphatase (ALP), osteopontin, osteocalcin, FGF23, and
SOST mRNA levels were not affected by increasing concentrations of calcium.

\section{Effects of Calcium on mRNA Levels of the Calcium Sensing Receptor (CaSR) in Primary Human Osteoblasts}

Primary human osteoblasts expressed extremely low CaSR mRNA levels (Fig. 4). Increasing concentrations of calcium did also not stimulate mRNA levels of CaSR.

\section{Effects of MEPE on mRNA Levels of CYP27B1 and VDR in Primary Human Osteoblasts}

Increasing concentrations of rhMEPE $(0.05-5 \mathrm{ug} / \mathrm{ml}) \mathrm{did}$ not affect mRNA levels of CYP27B1 and VDR (Fig. 5a, b, respectively).

\section{Discussion}

The enzyme $1 \alpha$-hydroxylase catalyzes the synthesis of $1,25(\mathrm{OH})_{2} \mathrm{D}$ in both renal and bone cells $[2,11]$. While renal $1 \alpha$-hydroxylase is tightly regulated by hormones and $1,25(\mathrm{OH})_{2} \mathrm{D}$ itself [61], the regulation of $1 \alpha$-hydroxylase in bone cells is poorly understood. We hypothesized that all renal regulators did not affect CYP27B1 mRNA levels. In contrast to our hypothesis, we observed that primary human osteoblasts in the presence of high calcium concentrations increase their CYP27B1 mRNA levels. Thus, calcium appears to play a role in the regulation of $1 \alpha$ hydroxylase in both kidney and bone tissue. However, high serum calcium concentrations reduce CYP27B1 expression levels in the kidney [9], while we observed the opposite effect in bone cells.

Changes in extracellular calcium concentrations can occur during bone remodeling [20]. In vitro studies show that human osteoblasts respond to high calcium concentrations by an increased chemotaxis and proliferation [12, 22, 36, 48]. High extracellular calcium concentrations also lead to stimulation of osteoblast differentiation markers as shown in fetal rat calvarial cells [16], and an enhanced formation of mineralized nodules [16, 64]. In late mature and mineralizing cultures of primary mouse osteoblasts, the CYP27B1 activity is higher compared to less differentiated osteoblasts [3]. Therefore, we hypothesized that primary human osteoblasts in our study were stimulated to differentiate in the presence of high calcium concentrations resulting in higher CYP27B1 expression. Indeed, high calcium concentrations increased mRNA levels of DMP1 which is a marker of the osteocyte [10]. As the cells used in our study were mature osteoblasts (Supplementary Fig.), the high calcium concentrations may have stimulated the 
Fig. 1 Effects of PTH1-34, rhFGF23, and calcitonin on mRNA levels of CYP27B1 and VDR in primary human osteoblasts. CYP27B1 and VDR mRNA levels were determined after $24 \mathrm{~h}$ incubation of primary human osteoblasts in medium supplemented with increasing concentrations of PTH1-34 ( $\mathbf{a}$ and $\mathbf{b}$, respectively), rhFGF23 (c and d, respectively), or calcitonin (e and $\mathbf{f}$, respectively). Results (mean \pm SEM) are expressed as treatment versus control ratios (control was set at 1.0; dashed line) using cells from 4 to 6 different donors
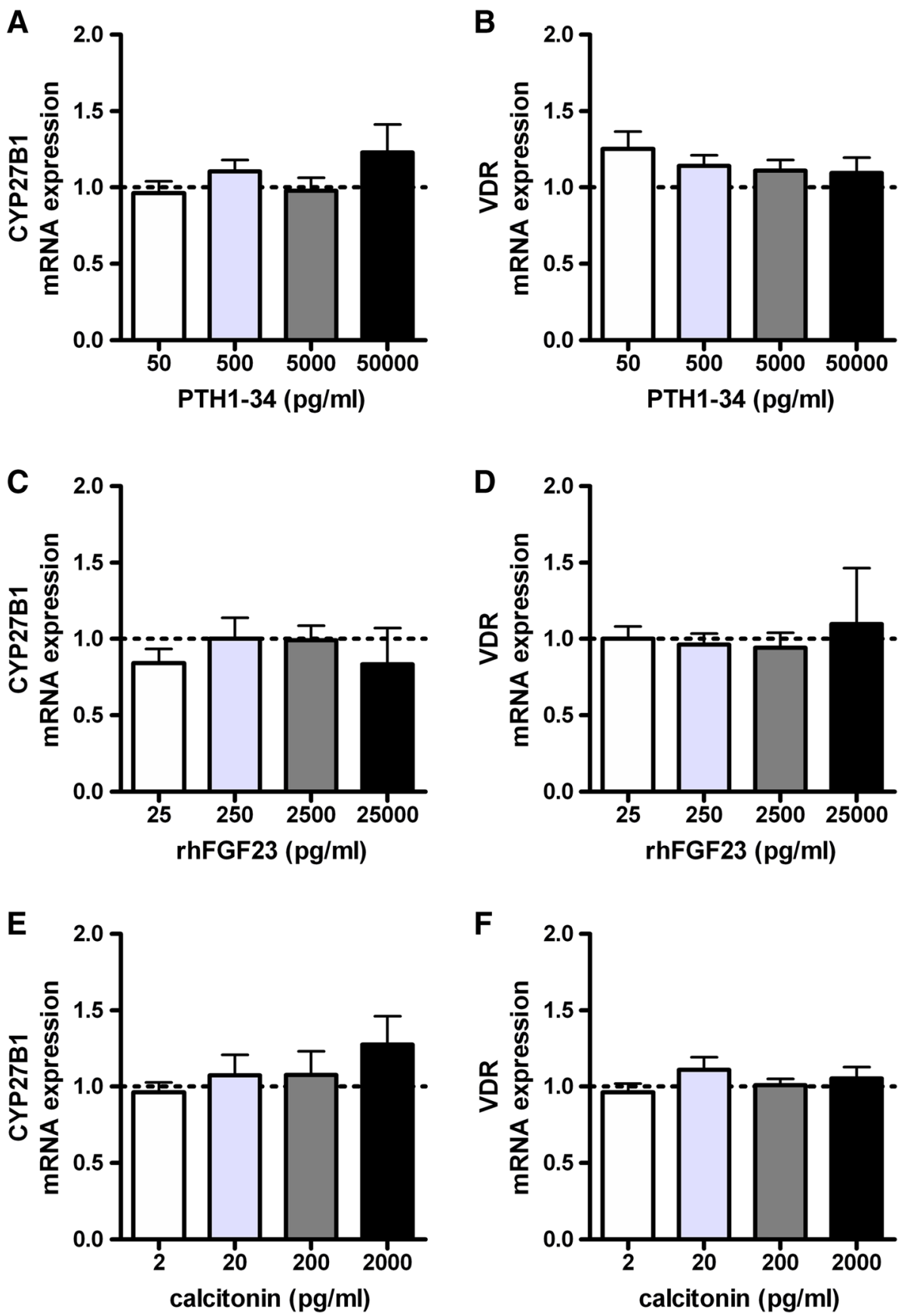

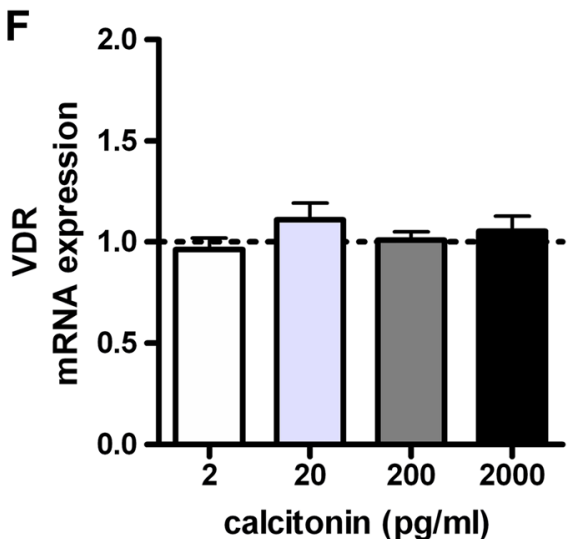

osteoblasts in culture to differentiate. Thus, the increased expression of CYP27B1 in the presence of high calcium is most likely a result of an increased maturation state.

The mechanism by which bone cells sense changes in extracellular calcium has been reported to occur through the CaSR, which is a member of the guanine nucleotide-binding protein (G-protein)-coupled receptor (GPCR) family [13]. Studies using fetal rat calvarial cells and clonal murine osteoblast cells suggest that the CaSR is involved in the stimulatory effects of calcium on osteoblast differentiation since these effects are mimicked by CaSR agonists [16].
Moreover, abolition of the CaSR reduces osteoblast differentiation and mineralization in mouse MC3T3-E1 cells [64]. This suggests that the increase of DMP1 mRNA levels under high calcium conditions may have occurred at least in part through activation of the CaSR. In our study, however, primary human osteoblasts expressed extremely low CaSR mRNA levels, even in the presence of high calcium concentrations. This finding raises the question whether other calcium sensing mechanisms may be involved [38, 49].

Increased CYP27B1 mRNA levels in osteoblasts under high calcium conditions may have positive effects on bone, 
Fig. 2 Effects of calcium and phosphate on mRNA levels of CYP27B1 and VDR in primary human osteoblasts. CYP27B1 and VDR mRNA levels were determined after $24 \mathrm{~h}$ incubation of primary human osteoblasts in medium supplemented with increasing concentrations of calcium (a and $\mathbf{b}$, respectively) or phosphate (c and $\mathbf{d}$, respectively). Results (mean \pm SEM) are expressed as treatment versus control ratios (control was set at 1.0; dashed line) using cells from 5 different donors. $(* * p<0.01)$
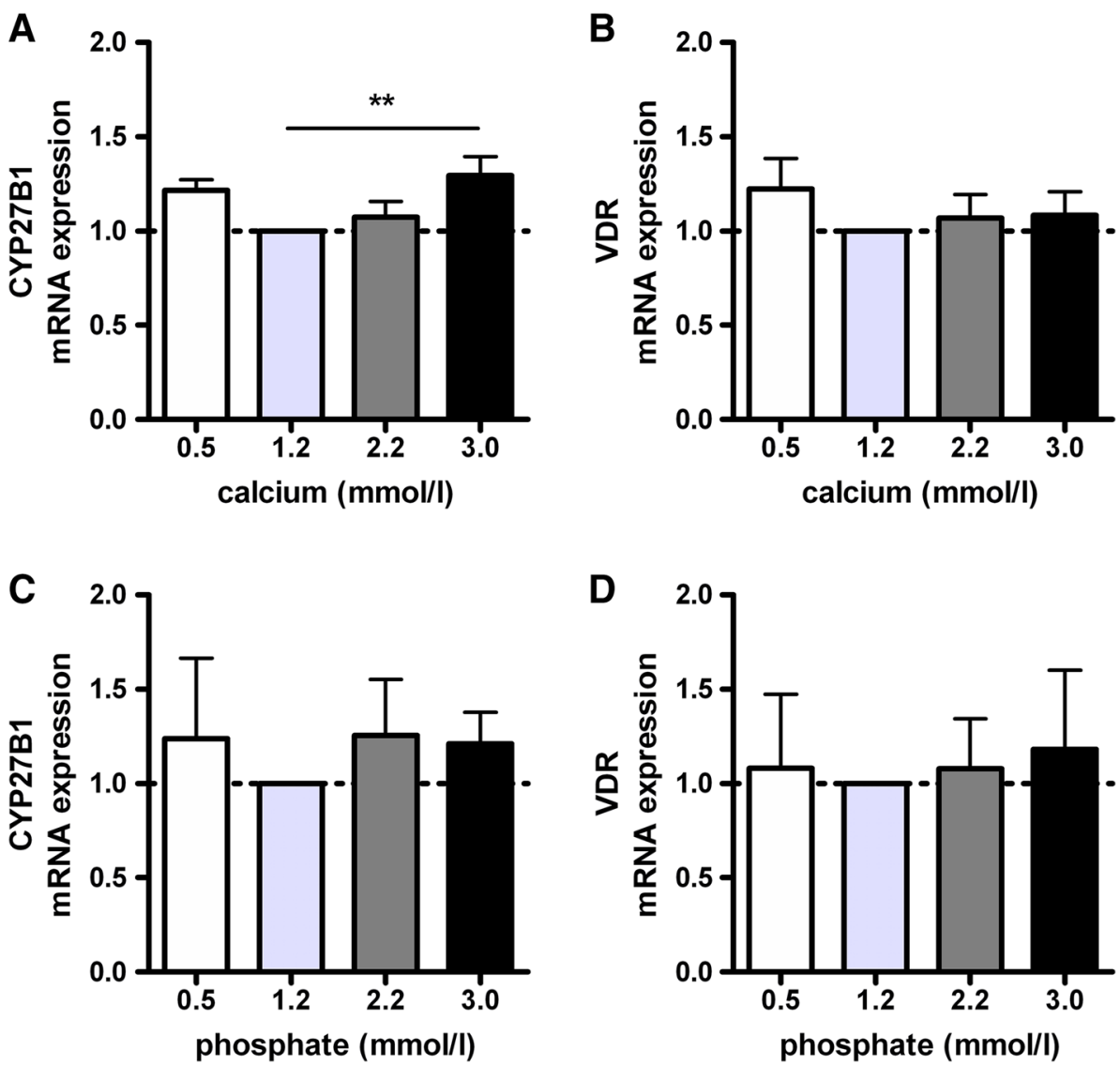

because increased CYP27B1 expression levels may lead to higher $1,25(\mathrm{OH})_{2} \mathrm{D}$ concentrations locally. High $1,25(\mathrm{OH})_{2} \mathrm{D}$ concentrations stimulate not only osteoblast differentiation, but also mineralization [5, 59] which is possible in the presence of high calcium. High calcium intake by rats also leads to increased mRNA levels of CYP27B1 in bone compared to rats with a low calcium intake [3]. CYP24 mRNA levels were also higher in bones from rats with a high calcium intake compared to rats fed a low calcium diet [3], suggesting that $1,25(\mathrm{OH})_{2} \mathrm{D}$ concentrations in bone tissue were higher in rats fed a high calcium diet [3, 42]. Thus, the increased synthesis of $1,25(\mathrm{OH})_{2} \mathrm{D}$ by bone cells under high calcium conditions may contribute at least partially to the stimulatory effect of calcium on matrix mineralization, as proposed previously [42].

The availability and the impact of locally synthesized $1,25(\mathrm{OH})_{2} \mathrm{D}$ not only depend on the activity of $1 \alpha$-hydroxylase, but also on the expression of VDR and the activity of 24-hydroxylase. In our study, CYP24 mRNA levels were extremely low or even undetectable in some donors (data not shown). VDR mRNA levels were not affected by increased concentrations of calcium, suggesting that the response of osteoblasts to $1,25(\mathrm{OH})_{2} \mathrm{D}$ is unchanged under high calcium conditions.
PTH exerts its effects through binding to the PTH receptor 1 (PTH1R) leading to actions to regulate bone remodeling [53]. In our study, PTH1-34 did not stimulate the expression of CYP27B1 which is in line with other in vitro studies using ROS and SV-HFO osteoblasts [55, 59]. In addition to in vitro studies, PTH does also not stimulate CYP27B1 mRNA levels in vivo [3]. Our results are in contrast to a study performed in human mesenchymal stem cells in which PTH1-34 increased CYP27B1 expression and $1,25(\mathrm{OH})_{2} \mathrm{D}$ synthesis [21]. This suggests a different regulation of CYP27B1 in osteoblasts compared to mesenchymal stem cells which seems to depend on the maturation state [60]. Another study in primary human bone cells showed that PTH1-84 increased CYP27B1 mRNA expression and $1,25(\mathrm{OH})_{2} \mathrm{D}$ synthesis, but concentrations of PTH1-84 $(66 \mathrm{nmol} / \mathrm{l})$ in that study were much higher compared to our study [54].

The primary role of calcitonin is to inhibit osteoclast activity leading to reduced bone resorption [27], but several studies have shown that calcitonin also affects osteoblast function [17, 18]. Osteoblast proliferation and alkaline phosphatase activity increase in the presence of calcitonin $[17,18]$. Thus calcitonin is able to affect osteoblast proliferation and differentiation, but our results suggests that 

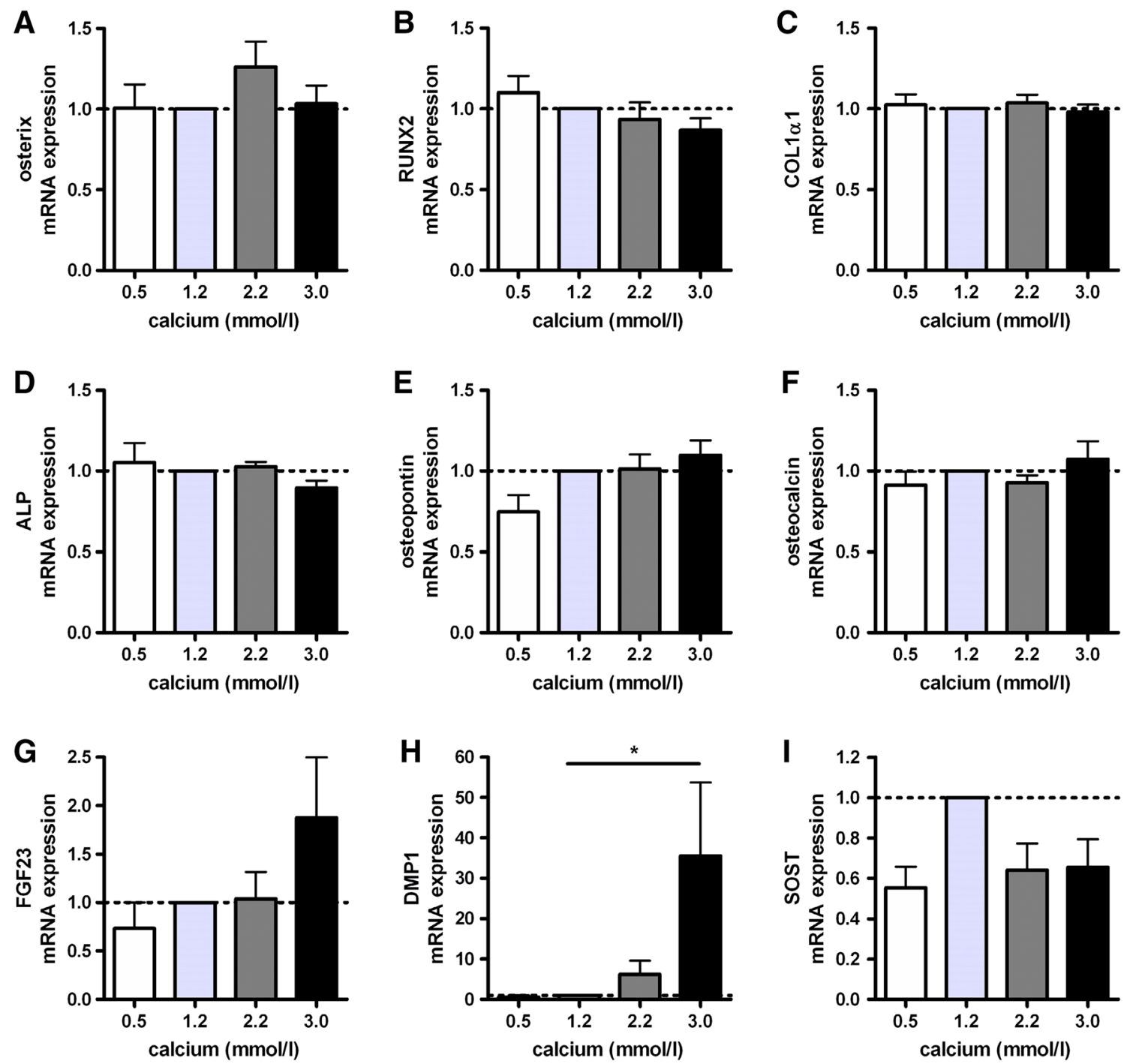

Fig. 3 Effects of calcium on differentiation markers in primary human osteoblasts. Osterix (a), RUNX2 (b), COL1 11 (c), ALP (d), osteopontin (e), osteocalcin (f), FGF23 (g), DMP1 (h), and SOST (i) mRNA levels were determined after $24 \mathrm{~h}$ incubation of primary

the local synthesis of $1,25(\mathrm{OH})_{2} \mathrm{D}$ is not involved in the actions of calcitonin.

Changes in phosphate concentrations did not appear to affect CYP27B1 mRNA levels in primary human osteoblasts. This is in contrast to a study in mouse osteocytes in which high phosphate concentrations (4 and $10 \mathrm{mmol} / \mathrm{l}$ ) stimulate CYP27B1 mRNA levels dose-dependently [29], but those phosphate concentrations were much higher than we used in our study. Regarding FGF23, effects of high concentrations have been shown on bone cells in vitro despite undetectable Klotho mRNA levels [63]. In fetal rat calvarial cell cultures, overexpression of FGF23 leads to the suppression of osteoblast differentiation and matrix mineralization [63]. In our study, incubation of human human osteoblasts in medium supplemented with increasing concentrations of calcium. Results (mean \pm SEM) are expressed as treatment versus control ratios (control was set at 1.0; dashed line) using cells from 5 different donors. $\left({ }^{*} p<0.05\right)$

osteoblasts in the presence of both physiological and supraphysiological concentrations of FGF23 did not result in altered CYP27B1 mRNA levels. This suggests that FGF23 does not regulate CYP27B1 expression in bone cells.

Consistent with previous animal and in vitro studies [3, 55, 59], our study suggests that CYP27B1 is regulated differently in bone compared with the kidney. Differences in regulation may be explained by differences in the contribution of repressor and enhancer elements in the $5^{\prime}$ flanking region of the CYP27B1 gene [55]. The difference in regulation of $1 \alpha$-hydroxylase in bone tissue compared to renal $1 \alpha$-hydroxylase possibly exists due to the differences in function. Locally synthesized $1,25(\mathrm{OH})_{2} \mathrm{D}$ does not function through endocrine pathways, but acts via 


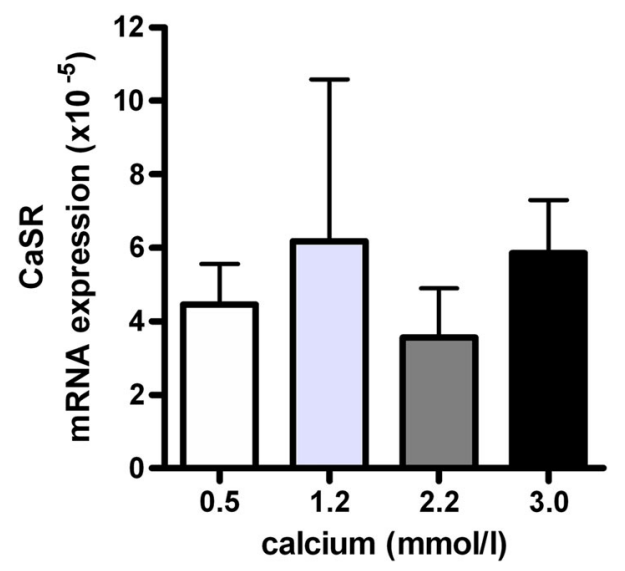

Fig. 4 Effects of calcium on CaSR mRNA levels in primary human osteoblasts. CaSR mRNA levels were determined after $24 \mathrm{~h}$ incubation of primary human osteoblasts in medium supplemented with increasing concentrations of calcium. Results are expressed as mean \pm SEM using cells from 5 different donors

autocrine and paracrine mechanisms to stimulate osteoblast differentiation and matrix mineralization $[5,58,59]$. To answer local demands, $1 \alpha$-hydroxylase should be regulated at a local level. Local factors such as interleukin- $1 \beta$ and TGF- $\beta$, respectively, increase and decrease CYP27B1 expression levels in bone cells [55, 59]. Recently, it has been shown that mechanical loading also stimulates CYP27B1 mRNA levels in primary human osteoblasts [57]. Thus, the regulation of $1 \alpha$-hydroxylase in bone appears to be tissue-specific.

We hypothesized that MEPE reduces CYP27B1 mRNA in human osteoblasts due to the inhibitory role of MEPE in bone mineralization. The inhibition of bone mineralization by MEPE has been related to the acidic serine- and aspartate-rich motif (ASARM) [34, 40, 50]. This small peptide is released after cleavage by cathepsin B and can

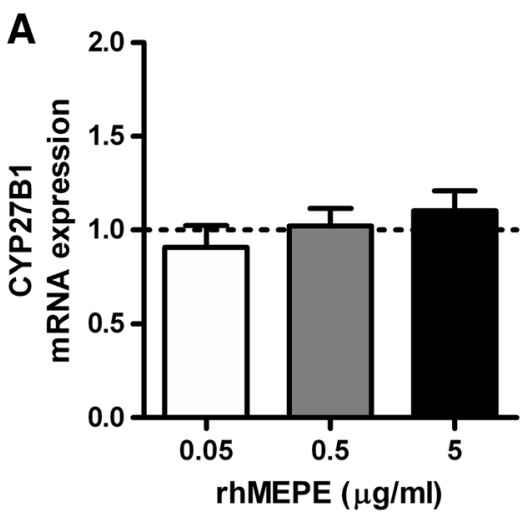

Fig. 5 Effects of rhMEPE on mRNA levels of CYP27B1 and VDR in primary human osteoblasts. CYP27B1 and VDR mRNA levels were determined after $24 \mathrm{~h}$ incubation of primary human osteoblasts in medium supplemented with increasing concentrations of rhMEPE bind to the hydroxyapatite crystal and, in turn, inhibit mineralization $[1,40]$. The cleavage by cathepsin B can be prevented by an interaction of MEPE with PHEX [1]. In culture, ASARM peptides may be released after cleavage by cathepsin B which is expressed by osteoblasts [51]. Due to the overload of MEPE in culture, the capacity of expressed PHEX is most likely too low to prevent MEPE from cathepsin B cleavage, as suggested previously [51]. In our culture ASARM peptides could be present, but effects on CYP27B1 mRNA levels were not observed.

A limitation of this study is that only one time-point (24 h) was tested, while measurements of CYP27B1 mRNA levels on earlier or later time-points may give different results. The 24-h time-point was chosen based on other studies in which effects of factors such as interleukin$1 \beta$ and TGF- $\beta$ on CYP27B1 mRNA levels were also demonstrated after $24 \mathrm{~h}$ incubation $[55,59]$. Another point that can be made is that the response of osteoblasts to the applied treatments may depend on the differentiation state. We used mature osteoblasts as determined by the measurement of mRNA levels of several differentiation markers (Supplementary Fig.), but it is possible that immature osteoblasts respond differently to treatments such as calcium and phosphate. Note, however, that increased CYP27B1 mRNA levels under high calcium conditions do not necessarily result in increased enzyme activity.

In conclusion, this in vitro study shows that MEPE as well as the renal regulators PTH, FGF23, phosphate, and calcitonin do not affect CYP27B1 mRNA levels in human bone cells. On the contrary, calcium positively affects CYP27B1 mRNA which suggests that the local synthesis of $1,25(\mathrm{OH})_{2} \mathrm{D}$ contributes to the stimulatory effect of calcium on matrix mineralization.

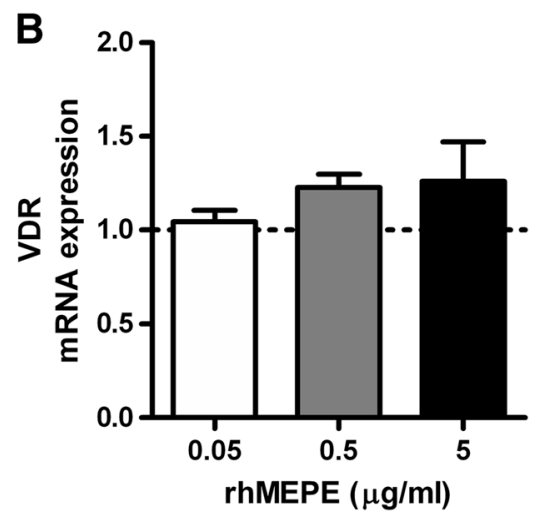

(a and b, respectively). Results (mean \pm SEM) are expressed as treatment versus control ratios (control was set at 1.0; dashed line) using cells from 5 different donors 


\section{Compliance with Ethical Standards}

Conflict of Interest K. van der Meijden, H.W. van Essen, F.W. Bloemers, E.A.J.M. Schulten, and N. Bravenboer have nothing to disclose. Dr. Lips reports personal fees from Friesland Campina, outside the submitted work.

Human and Animal Rights and Informed Consent All procedures performed in studies involving human participants were in accordance with the ethical standards of the institutional and/or national research committee and with the 1964 Helsinki declaration and its later amendments or comparable ethical standards.

Open Access This article is distributed under the terms of the Creative Commons Attribution 4.0 International License (http://crea tivecommons.org/licenses/by/4.0/), which permits unrestricted use, distribution, and reproduction in any medium, provided you give appropriate credit to the original author(s) and the source, provide a link to the Creative Commons license, and indicate if changes were made.

\section{References}

1. Addison WN, Nakano Y, Loisel T, Crine P, McKee MD (2008) MEPE-ASARM peptides control extracellular matrix mineralization by binding to hydroxyapatite: an inhibition regulated by PHEX cleavage of ASARM. J Bone Miner Res 23:1638-1649

2. Anderson PH, Atkins GJ (2008) The skeleton as an intracrine organ for vitamin D metabolism. Mol Aspects Med 29:397-406

3. Anderson PH, Iida S, Tyson JH, Turner AG, Morris HA (2010) Bone CYP27B1 gene expression is increased with high dietary calcium and in mineralising osteoblasts. J Steroid Biochem Mol Biol 121:71-75

4. Anderson PH, O'Loughlin PD, May BK, Morris HA (2005) Modulation of CYP27B1 and CYP24 mRNA expression in bone is independent of circulating $1,25(\mathrm{OH})_{2} \mathrm{D}_{3}$ levels. Bone 36:654-662

5. Atkins GJ, Anderson PH, Findlay DM, Welldon KJ, Vincent C, Zannettino AC, O'Loughlin PD, Morris HA (2007) Metabolism of vitamin $\mathrm{D}_{3}$ in human osteoblasts: evidence for autocrine and paracrine activities of 1 1, 25 -dihydroxyvitamin $D_{3}$. Bone 40:1517-1528

6. Atkins GJ, Welldon KJ, Holding CA, Haynes DR, Howie DW, Findlay DM (2009) The induction of a catabolic phenotype in human primary osteoblasts and osteocytes by polyethylene particles. Biomaterials 30:3672-3681

7. Bacchetta J, Sea JL, Chun RF, Lisse TS, Wesseling-Perry K, Gales B, Adams JS, Salusky IB, Hewison M (2013) Fibroblast growth factor 23 inhibits extrarenal synthesis of 1,25-dihydroxyvitamin D in human monocytes. J Bone Miner Res 28:46-55

8. Beresford JN, Gallagher JA, Gowen M, McGuire MKB, Poser JW, RGG Russell (1983) Human bone cells in culture: a novel system for the investigation of bone cell metabolism. Clin Sci 64:33-39

9. Bland R, Walker EA, Hughes SV, Stewart PM, Hewison M (1999) Constitutive expression of 25 -hydroxyvitamin $D_{3}-1 \alpha$-hydroxylase in a transformed human proximal tubule cell line: evidence for direct regulation of vitamin $\mathrm{D}$ metabolism by calcium. Endocrinology 140:2027-2034

10. Bonewald LF (2011) The amazing osteocyte. J Bone Miner Res 26:229-238

11. Brunette MG, Chan M, Ferriere C, Roberts KD (1978) Site of $1,25(\mathrm{OH}) 2$ vitamin D3 synthesis in the kidney. Nature 276:287-289
12. Chattopadhyay N, Yano S, Tfelt-Hansen J, Rooney P, Kanuparthi D, Bandyopadhyay S, Ren X, Terwilliger E, Brown EM (2004) Mitogenic action of calcium-sensing receptor on rat calvarial osteoblasts. Endocrinology 145:3451-3462

13. Cianferotti L, Gomes AR, Fabbri S, Tanini A, Brandi ML (2015) The calcium-sensing receptor in bone metabolism: from bench to bedside and back. Osteoporos Int 26:2055-2071

14. Condamine L, Menaa C, Vrtovsnik F, Friedlander G, Garabedian M (1994) Local action of phosphate depletion and insulin-like growth factor 1 on in vitro production of 1,25-dihydroxyvitamin $\mathrm{D}$ by cultured mammalian kidney cells. J Clin Invest 94:1673-1679

15. Dobbie H, Unwin RJ, Faria NJ, Shirley DG (2008) Matrix extracellular phosphoglycoprotein causes phosphaturia in rats by inhibiting tubular phosphate reabsorption. Nephrol Dial Transplant 23:730-733

16. Dvorak MM, Siddiqua A, Ward DT, Carter DH, Dallas SL, Nemeth EF, Riccardi D (2004) Physiological changes in extracellular calcium concentration directly control osteoblast function in the absence of calciotropic hormones. Proc Natl Acad Sci USA 101:5140-5145

17. Farley JR, Hall SL, Tarbaux NM (1989) Calcitonin (but not calcitonin gene-related peptide) increases mouse bone cell proliferation in a dose-dependent manner, and increases mouse bone formation, alone and in combination with fluoride. Calcif Tissue Int 45:214-221

18. Farley JR, Wergedal JE, Hall SL, Herring S, Tarbaux NM (1991) Calcitonin has direct effects on $3[\mathrm{H}]$-thymidine incorporation and alkaline phosphatase activity in human osteoblast-line cells. Calcif Tissue Int 48:297-301

19. Fukase M, Birge SJ Jr, Rifas L, Avioli LV, Chase LR (1982) Regulation of 25 hydroxyvitamin $\mathrm{D}_{3}$ 1-hydroxylase in serum-free monolayer culture of mouse kidney. Endocrinology 110:10731075

20. Gabusi E, Manferdini C, Grassi F, Piacentini A, Cattini L, Filardo G, Lambertini E, Piva R, Zini N, Facchini A, Lisignoli G (2012) Extracellular calcium chronically induced human osteoblasts effects: specific modulation of osteocalcin and collagen type XV. J Cell Physiol 227:3151-3161

21. Geng S, Zhou S, Glowacki J (2011) Age-related decline in osteoblastogenesis and $1 \alpha$-hydroxylase/CYP27B1 in human mesenchymal stem cells: stimulation by parathyroid hormone. Aging Cell 10:962-971

22. Godwin SL, Soltoff SP (1997) Extracellular calcium and plateletderived growth factor promote receptor-mediated chemotaxis in osteoblasts through different signaling pathways. J Biol Chem 272:11307-11312

23. Gowen LC, Petersen DN, Mansolf AL, Qi H, Stock JL, Tkalcevic GT, Simmons HA, Crawford DT, Chidsey-Frink KL, Ke HZ, McNeish JD, Brown TA (2003) Targeted disruption of the osteoblast/osteocyte factor 45 gene (OF45) results in increased bone formation and bone mass. J Biol Chem 278:1998-2007

24. Gray RW (1981) Control of plasma $1,25-(\mathrm{OH})_{2}$-vitamin D concentrations by calcium and phosphorus in the rat: effects of hypophysectomy. Calcif Tissue Int 33:485-488

25. Halloran BP, Spencer EM (1988) Dietary phosphorus and 1,25dihydroxyvitamin D metabolism: influence of insulin-like growth factor I. Endocrinology 123:1225-1229

26. Hewison M, Zehnder D, Bland R, Stewart PM (2000) 1 $\alpha-\mathrm{Hy}-$ droxylase and the action of vitamin D. J Mol Endocrinol 25:141-148

27. Holt E, Wysolmerski JJ (2011) Parathyroid hormone, parathyroid hormone-related protein, and calcitonin. In: Feldman D, Pike JW, Adams JS (eds) Vitamin D, 3rd edn. Academic Press, San Diego, pp 725-745

28. Horiuchi N, Takahashi H, Matsumoto $\mathrm{T}$, Takahashi N, Shimazawa E, Suda T, Ogata E (1979) Salmon calcitonin-induced 


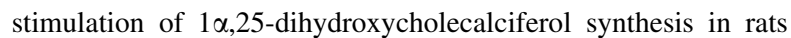
involving a mechanism independent of adenosine $3^{\prime}: 5^{\prime}$-cyclic monophosphate. Biochem J 184:269-275

29. Ito N, Findlay DM, Anderson PH, Bonewald LF, Atkins GJ (2013) Extracellular phosphate modulates the effect of $1 \alpha, 25$ dihydroxy vitamin $\mathrm{D}_{3}(1,25 \mathrm{D})$ on osteocyte like cells. J Steroid Biochem Mol Biol 136:183-186

30. Jung SY, Kwak JO, Kim HW, Kim DS, Ryu SD, Ko CB, Cha SH (2005) Calcium sensing receptor forms complex with and is upregulated by caveolin-1 in cultured human osteosarcoma (Saos-2) cells. Exp Mol Med 37:91-100

31. Kawashima H, Torikai S, Kurokawa K (1981) Calcitonin selectively stimulates 25 -hydroxyvitamin $\mathrm{D}_{3}-1 \alpha$-hydroxylase in proximal straight tubule of rat kidney. Nature 291:327-329

32. Kulkarni RN, Bakker AD, Everts V, Klein-Nulend J (2010) Inhibition of osteoclastogenesis by mechanically loaded osteocytes: involvement of MEPE. Calcif Tissue Int 87:461-468

33. Lips P (2006) Vitamin D physiology. Prog Biophys Mol Biol 92:4-8

34. Machado JP, Johnson WE, O'Brien SJ, Vasconcelos V, Antunes A (2011) Adaptive evolution of the matrix extracellular phosphoglycoprotein in mammals. BMC Evol Biol 11:342

35. Maeno S, Niki $Y$, Matsumoto $H$, Morioka $H$, Yatabe $T$, Funayama A, Toyama Y, Taguchi T, Tanaka J (2005) The effect of calcium ion concentration on osteoblast viability, proliferation and differentiation in monolayer and $3 \mathrm{D}$ culture. Biomaterials 26:4847-4855

36. Mailland M, Waelchli R, Ruat M, Boddeke HG, Seuwen K (1997) Stimulation of cell proliferation by calcium and a calcimimetic compound. Endocrinology 138:3601-3605

37. Marie PJ, Lomri A, Sabbagh A, Basle M (1989) Culture and behavior of osteoblastic cells isolated from normal trabecular bone surfaces. In Vitro Cell Dev Biol 25:373-380

38. Marie PJ (2010) The calcium-sensing receptor in bone cells: a potential therapeutic target in osteoporosis. Bone 46:571-576

39. Marks J, Churchill LJ, Debnam ES, Unwin RJ (2008) Matrix extracellular phosphoglycoprotein inhibits phosphate transport. J Am Soc Nephrol 19:2313-2320

40. Martin A, David V, Laurence JS, Schwarz PM, Lafer EM, Hedge AM, Rowe PS (2008) Degradation of MEPE, DMP1, and release of SIBLING ASARM-peptides (minhibins): ASARM-peptide(s) are directly responsible for defective mineralization in HYP. Endocrinology 149:1757-1772

41. Martin A, David V, Quarles LD (2012) Regulation and function of the FGF23/klotho endocrine pathways. Physiol Rev 92:131-155

42. Morris HA, O'Loughlin PD, Anderson PH (2010) Experimental evidence for the effects of calcium and vitamin D on bone: a review. Nutrients 2:1026-1035

43. Murayama A, Takeyama K, Kitanaka S, Kodera Y, Kawaguchi Y, Hosoya T, Kato S (1999) Positive and negative regulations of the renal 25-hydroxyvitamin $\mathrm{D}_{3} 1 \alpha$-hydroxylase gene by parathyroid hormone, calcitonin, and $1 \alpha, 25(\mathrm{OH})_{2} \mathrm{D}_{3}$ in intact animals. Endocrinology 140:2224-2231

44. Nampei A, Hashimoto J, Hayashida K, Tsuboi H, Shi K, Tsuji I, Miyashita H, Yamada T, Matsukawa N, Matsumoto M, Morimoto S, Ogihara T, Ochi T, Yoshikawa H (2004) Matrix extracellular phosphoglycoprotein (MEPE) is highly expressed in osteocytes in human bone. J Bone Miner Metab 22:176-184

45. Perwad F, Portale AA (2011) Vitamin D metabolism in the kidney: regulation by phosphorus and fibroblast growth factor 23 . Mol Cell Endocrinol 347:17-24

46. Petersen DN, Tkalcevic GT, Mansolf AL, Rivera-Gonzalez R, Brown TA (2000) Identification of osteoblast/osteocyte factor 45 (OF45), a bone-specific cDNA encoding an RGD-containing protein that is highly expressed in osteoblasts and osteocytes. J Biol Chem 275:36172-36180
47. Quarles LD (2012) Skeletal secretion of FGF-23 regulates phosphate and vitamin D metabolism. Nat Rev Endocrinol 8:276-286

48. Quarles LD, Hartle JE, Middleton JP, Zhang J, Arthur JM, Raymond JR (1994) Aluminum-induced DNA synthesis in osteoblasts: mediation by a G-protein coupled cation sensing mechanism. J Cell Biochem 56:106-117

49. Quarles LD (1997) Cation sensing receptors in bone: a novel paradigm for regulating bone remodeling? J Bone Miner Res 12:1971-1974

50. Rowe PS, de Zoysa PA, Dong R, Wang HR, White KE, Econs MJ, Oudet CL (2000) MEPE, a new gene expressed in bone marrow and tumors causing osteomalacia. Genomics 67:54-68

51. Rowe PS, Kumagai Y, Gutierrez G, Garrett IR, Blacher R, Rosen D, Cundy J, Navvab S, Chen D, Drezner MK, Quarles LD, Mundy GR (2004) MEPE has the properties of an osteoblastic phosphatonin and minhibin. Bone 34:303-319

52. Shinki T, Ueno Y, DeLuca HF, Suda T (1999) Calcitonin is a major regulator for the expression of renal 25-hydroxyvitamin $D_{3}-1 \alpha$-hydroxylase gene in normocalcemic rats. Proc Natl Acad Sci USA 96:8253-8258

53. Silva BC, Bilezikian JP (2015) Parathyroid hormone: anabolic and catabolic actions on the skeleton. Curr Opin Pharmacol 22:41-50

54. Somjen D, Katzburg S, Stern N, Kohen F, Sharon O, Limor R, Jaccard N, Hendel D, Weisman Y (2007) 25 hydroxy-vitamin $\mathrm{D}_{3^{-}}$ $1 \alpha$ hydroxylase expression and activity in cultured human osteoblasts and their modulation by parathyroid hormone, estrogenic compounds and dihydrotestosterone. J Steroid Biochem Mol Biol 107:238-244

55. Turner AG, Dwivedi PP, May BK, Morris HA (2007) Regulation of the CYP27B1 $5^{\prime}$-flanking region by transforming growth factor-beta in ROS 17/2.8 osteoblast-like cells. J Steroid Biochem Mol Biol 103:322-325

56. Urakawa I, Yamazaki Y, Shimada T, Iijima K, Hasegawa H, Okawa K, Fujita T, Fukumoto S, Yamashita T (2006) Klotho converts canonical FGF receptor into a specific receptor for FGF23. Nature 444:770-774

57. van der Meijden K, Bakker AD, van Essen HW, Heijboer AC, Schulten EAJM, Lips P, Bravenboer N (2015) Mechanical loading and the synthesis of $1,25(\mathrm{OH})_{2} \mathrm{D}$ in primary human osteoblasts. J Steroid Biochem Mol Biol. accepted

58. van der Meijden K, Lips P, van Driel M, Heijboer AC, Schulten EA, den Heijer M, Bravenboer N (2014) Primary Human Osteoblasts in Response to 25-Hydroxyvitamin $\mathrm{D}_{3}, 1,25$-Dihydroxyvitamin $\mathrm{D}_{3}$ and 24R,25-Dihydroxyvitamin $\mathrm{D}_{3}$. PLoS One 9:e110283

59. van Driel M, Koedam M, Buurman CJ, Hewison M, Chiba H, Uitterlinden AG, Pols HA, van Leeuwen JP (2006) Evidence for auto/paracrine actions of vitamin $\mathrm{D}$ in bone: $1 \alpha$-hydroxylase expression and activity in human bone cells. FASEB J. 20:2417-2419

60. van Driel M, van Leeuwen JP (2014) Vitamin D endocrine system and osteoblasts. Bonekey Rep 3:493

61. Verstuyf A, Carmeliet G, Bouillon R, Mathieu C (2010) Vitamin D: a pleiotropic hormone. Kidney Int 78:140-145

62. Villa I, Dal FC, Maestroni A, Rubinacci A, Ravasi F, Guidobono F (2003) Human osteoblast-like cell proliferation induced by calcitonin-related peptides involves PKC activity. Am J Physiol Endocrinol Metab 284:E627-E633

63. Wang H, Yoshiko Y, Yamamoto R, Minamizaki T, Kozai K, Tanne K, Aubin JE, Maeda N (2008) Overexpression of fibroblast growth factor 23 suppresses osteoblast differentiation and matrix mineralization in vitro. J Bone Miner Res 23:939-948

64. Yamauchi M, Yamaguchi T, Kaji H, Sugimoto T, Chihara K (2005) Involvement of calcium-sensing receptor in osteoblastic differentiation of mouse MC3T3-E1 cells. Am J Physiol Endocrinol Metab 288:E608-E616 